\title{
Acute myocardial infarction due to simultaneous occlusions of the left anterior descending artery and right coronary artery
}

\author{
Efe Edem, Perihan Varım, Mustafa Türker Pabuccu, Mehmet Bülent Vatan
}

Department of Cardiology, Sakarya University Training and Research Hospital, Sakarya, Turkey

\section{Correspondence to} Dr Efe Edem,

edemefe@yahoo.com

Accepted 29 April 2015

\section{DESCRIPTION}

Thrombosis of multiple coronary arteries at the same time is an uncommon angiographic finding during the course of ST-segment elevation myocardial infarction (STEMI). This clinical condition usually leads to cardiogenic shock or even sudden cardiac death. We present a case of a man who presented with STEMI due to simultaneous occlusions of the left anterior descending artery (LAD) and right coronary artery (RCA).

A 57-year-old man was referred to our emergency department due to central chest pain and ST-segment elevations in anterior and inferior leads (figure 1). He did not have any particular diseases or well-described risk factors in his medical history. Based on ECG findings, his LAD was thought to be the cause; however, his emergent coronary angiography revealed thrombi in the LAD as well as RCA. The LAD (videos 1-3) and RCA (videos 4-6) were successfully treated with stent implantations. The patient's laboratory tests, which included antithrombin III, protein $\mathrm{C}$ and protein $\mathrm{S}$ deficiencies, and activated protein $\mathrm{C}$ resistance, did not indicate any coagulation disorders. Lupus anticoagulant, anticardiolipin $\operatorname{IgM}$ and $\operatorname{IgG}$ were all negative. The patient's platelet count was $213000 / \mathrm{mm}^{3}$. Echocardiography performed before the procedure did not reveal any thrombus in the left ventricle

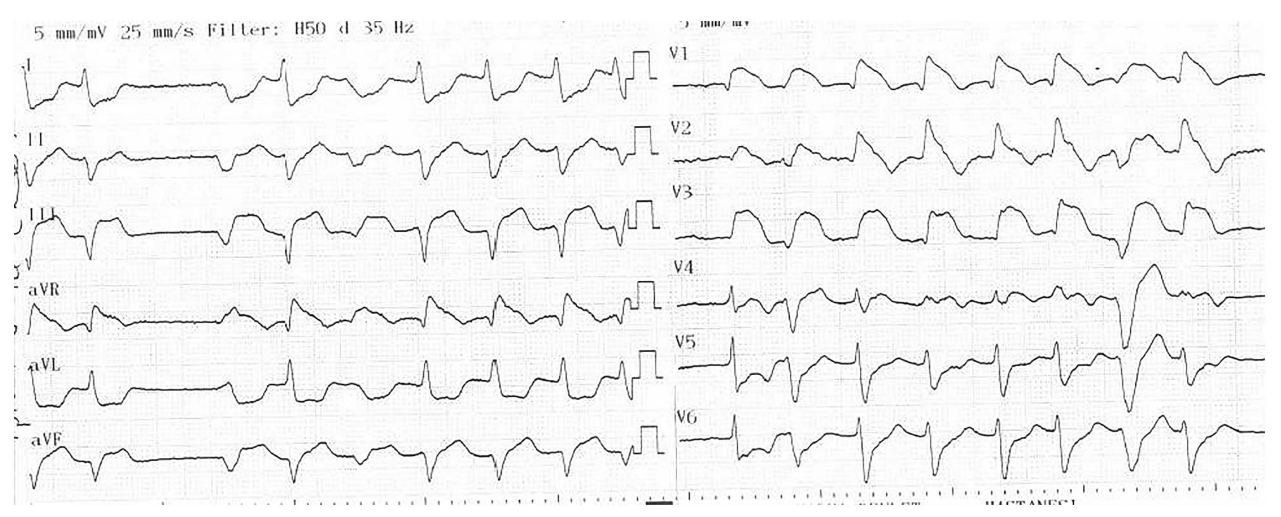

Figure 1 ST-segment elevations in inferior and anterior leads.

To cite: Edem $E$, Varım $P$, Pabuccu MT, et al. BMJ Case Rep Published online: [please include Day Month Year] doi:10.1136/bcr-2015209941

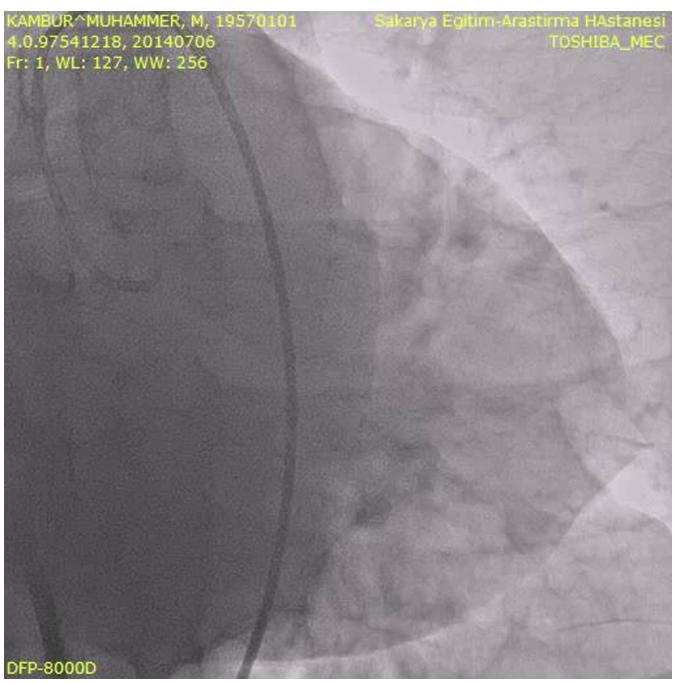

video 1 Proximal total occlusion of left anterior descending artery.

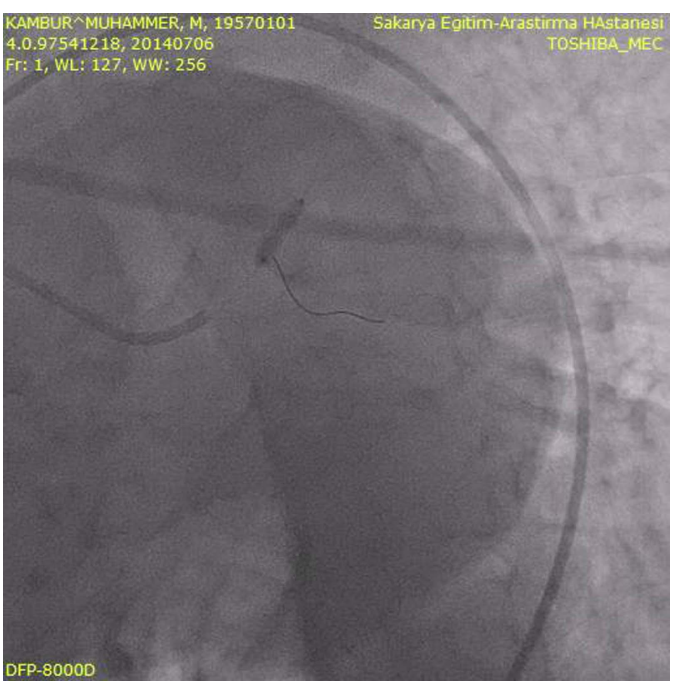

video 2 Endeavour resolute $3.0 / 15 \mathrm{~mm}$ drug-eluting stent (Medtronic Inc, Minneapolis, Minnesota, USA) implantation at 16 ATMs. 


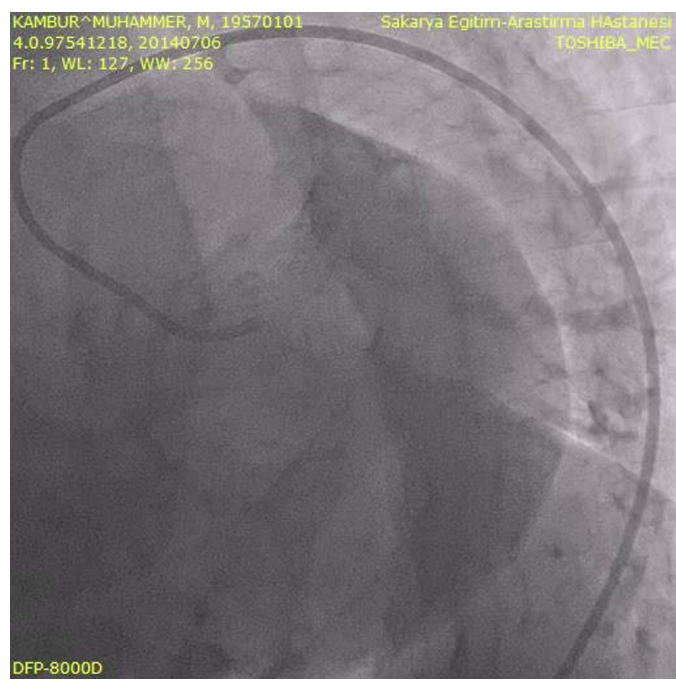

video 3 Final angiographic injection of left anterior descending artery.

and the patient did not have a history of atrial fibrillation before the acute coronary event.

Different possible underlying conditions causing double coronary artery occlusions during the course of STEMI have been suggested, such as cocaine use, a hypercoagulable state and essential thrombocytosis. ${ }^{1}$ However, the underlying mechanism still remains unclear in most of these patients, as in our case. Previous studies conducted via angioscopy and intravascular ultrasound demonstrated that multiple atherosclerotic plaque ruptures are frequent during the setting of acute coronary events and can be observed in different coronary vessels. Recently, Karabay et $a l^{2}$ also reported anterior and inferior myocardial infarctions in a patient due to simultaneous total occlusions of both the LAD and RCA. In 2015, Mahmoud et al conducted a systematic review on simultaneous multivessel thrombosis during STEMI, including 29 articles, which totally yielded 56 patients. They revealed that simultaneous thrombosis of the LAD and RCA was the most common angiographic finding in this clinical setting. ${ }^{3}$ It should always be kept in mind that coronary arteries must be examined properly during

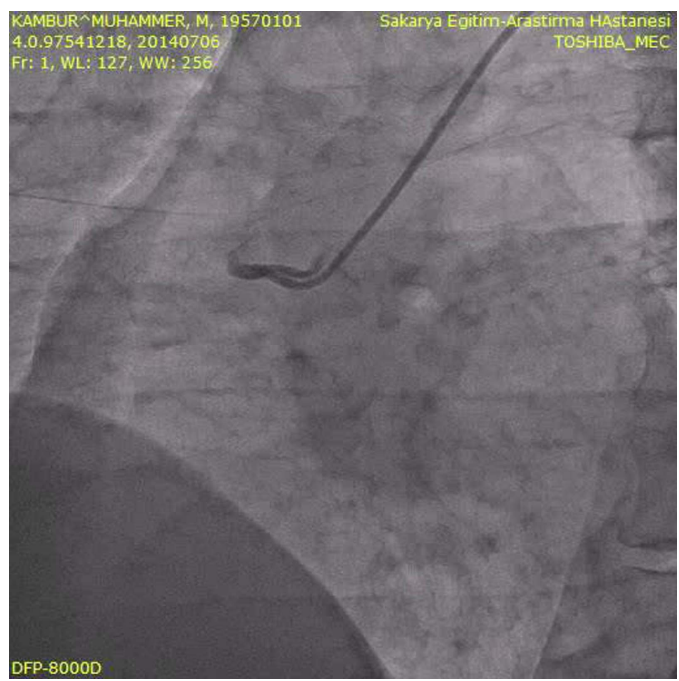

video 4 Proximal total occlusion of right coronary artery.

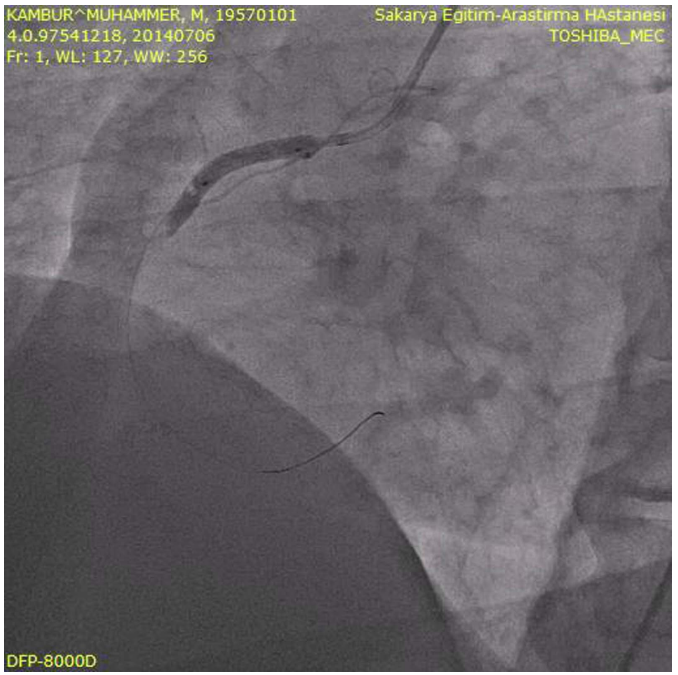

video 5 Ephesos 4.0/18 mm bare metal stent (Alvimedica, İstanbul, Turkey) implantation at 17 ATMs.

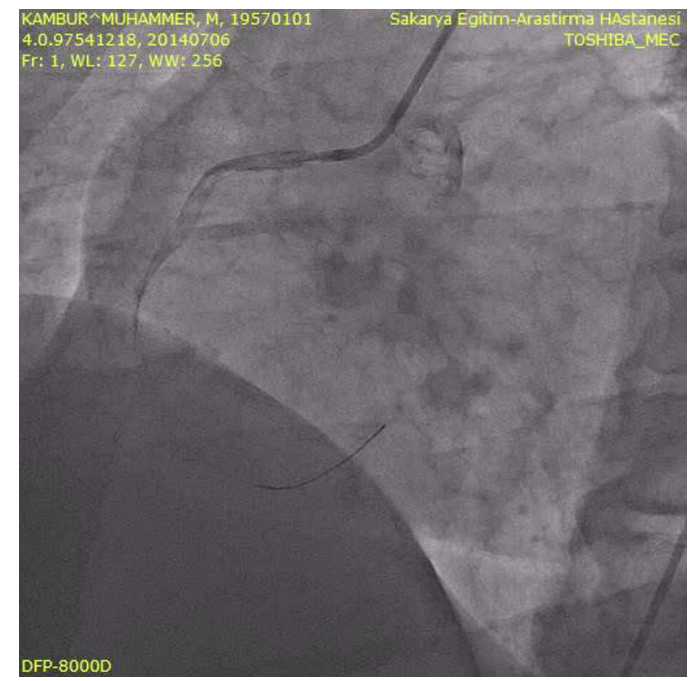

video 6 Final angiographic injection of right coronary artery.

emergent percutaneous coronary interventions, especially if the patient presented with cardiogenic shock or sudden cardiac death, or if multiple arteries are suspected to be the cause. Further studies are required in order to evaluate contributing factors causing extensive thrombosis in multiple coronary vessels in acute coronary syndromes.

\section{Learning points}

Despite the tendency to blame a single lesion as being the cause, ST-segment elevation myocardial infarction involving double coronary artery occlusions may occur. Therefore it is crucial to accurately diagnose the clinical condition and determine the appropriate treatment since most of these patients are hemodynamically and clinically unstable.

Competing interests None declared.

Patient consent Obtained. 
Provenance and peer review Not commissioned; externally peer reviewed.

\section{REFERENCES}

1 Kanie $\mathrm{Y}$, Janardhanan R, Fox JT, et al. Multivessel coronary artery thrombosis. $J$ Invasive Cardiol 2009;21:66-8.
2 Karabay KO, Yildiz A, Behramoglu F, et al. Concomitant anterior and inferior myocardial infarctions. Int J Angiol 2015;24:59-62.

3 Mahmoud A, Saad M, Elgendy IY. Simultaneous multi-vessel coronary thrombosis in patients with ST-elevation myocardial infarction: a systematic review. Cardiovasc Revasc Med 2015. Published Online First: 5 Mar 2015.

Copyright 2015 BMJ Publishing Group. All rights reserved. For permission to reuse any of this content visit

http://group.bmj.com/group/rights-licensing/permissions.

BMJ Case Report Fellows may re-use this article for personal use and teaching without any further permission.

Become a Fellow of BMJ Case Reports today and you can:

- Submit as many cases as you like

- Enjoy fast sympathetic peer review and rapid publication of accepted articles

- Access all the published articles

- Re-use any of the published material for personal use and teaching without further permission

For information on Institutional Fellowships contact consortiasales@bmjgroup.com

Visit casereports.bmj.com for more articles like this and to become a Fellow 